\title{
Novel Organotin(IV) Complexes, Derived from Chiral Benzimidazoles: Synthesis, Molecular Structure and Spectral Properties
}

\author{
A. AKREMI*1, A. NOUBIGH ${ }^{2}$ and M. J. A. ABUALREISH ${ }^{3}$ \\ 1,2,3 Department of Chemistry, Faculty of Sciences, Northern Border University, Arar 91431, \\ Kingdom of Saudi Arabia. \\ aDepartment of Chemistry, Faculty of Science, El Manar University, Tunis, Tunisia. (permentant address) \\ 'Laboratory of Physical Chemistry of Materials, Preparatory Institute for Scientific and Technical Studies of La Marsa, 2070, \\ Carthage University, Tunisia. (permentant address) \\ 'Department of Chemistry, Faculty of Science and Technology, Omdurman Islamic University, Sudan. (permentant address). \\ *Corresponding author E-mail: akrimimi@gmail.com \\ http://dx.doi.org/10.13005/ojc/340220
}

(Received: November 10, 2017; Accepted: January 10, 2018)

\section{ABSTRACT}

The synthesis of homoleptic five-coordinate heteroaryl tin(IV) compounds using three chiral $N$-heterocyclic substituents, 2-(1-aminoethyl)benzimidazole (1), 2-(pyrrolidin-2-yl) benzimidazole (2) and 2-(1-amino-2-mercaptopropylyl)benzimidazole (3) ligands is described. It has been found that ligands 1 and 2 behave in the bidentate $N, N$ donor fashion, however, ligand 3 behave in the bidentate $N, S$ donor. Overall ligands furnished, with moderate yields, their corresponding complexes $\left[\left(\mathrm{CH}_{3}\right)_{2} \mathrm{Sn}\left(\mathrm{C}_{9} \mathrm{H}_{10} \mathrm{~N}_{3}\right) \mathrm{Cl}\right](4),\left[\left(\mathrm{CH}_{3}\right)_{2} \mathrm{Sn}\left(\mathrm{C}_{9} \mathrm{H}_{12} \mathrm{~N}_{3}\right) \mathrm{Cl}\right]$ (5) and $\left[\left(\mathrm{CH}_{3}\right)_{2} \mathrm{Sn}\left(\mathrm{C}_{9} \mathrm{H}_{10} \mathrm{~N}_{3} \mathrm{~S}\right) \mathrm{Cl}\right](6)$. The characterization of all compounds by various spectroscopic methods UV-Vis, FT-IR, NMR, RX and elemental analyses provided insights into the diversity of complex formation.

Keywords: Five-coordinate, Heteroaryl tin(IV), Chiral benzimidazoles, Bidentate, Moderate yields.

\section{INTRODUCTION}

The organotin(IV) compounds have been widely investigated during the last few decades due to its multifaceted picture compromising a broad spectrum of biocidal properties, catalytic activity, use as stabilizers and appealing structural diversity ${ }^{1-11}$.

Structural studies have always been prominent in organotin chemistry, and particularly the structural changes which occur between the solution and solid states. The tin atom in the complexes can be penta-coordinated ${ }^{12-14}$ or hexa-coordinated ${ }^{15-18}$ and the complexes often show fluxional stereochemical behavior ${ }^{16,19}$.

On the other hand, benzimidazoles are known to exhibit a wide range of pharmacological properties including antiviral and antibacterial activities $^{20-23}$. Another feature of the benzimidazole ligands is functionalization at the non-coordinated 
nitrogen of the benzimidazole moiety, which provides a mode for modification of their properties.

In addition, chiral organometallic complexes exhibit various pharmacological properties. The binding of chiral drugs to DNA usually shows stereoselectivity, which affect their pharmacokinetic profiles and biochemical activities $^{24-26}$.

The present work describes the synthesis and characterization of three tin(IV) compounds derived from chiral bidentate ligands 2-(1-aminoethyl) benzimidazole (1), 2-(pyrrolidin-2-yl)benzimidazole (2) and tridentate ligand 2-(1-amino-2-mercaptop ropylyl) benzimidazole(3) (Scheme 1).

\section{RESULTS AND DISCUSSIONS}

2-Alkylamminobenzimidazoles $(\mathrm{ABzH})$ 1-3 have been synthesized from reaction of o-phenylenediamine with $L(+)$-alanine, $L(+)$-proline and $L(+)$-cysteine respectively (Scheme 1$)^{27}$.

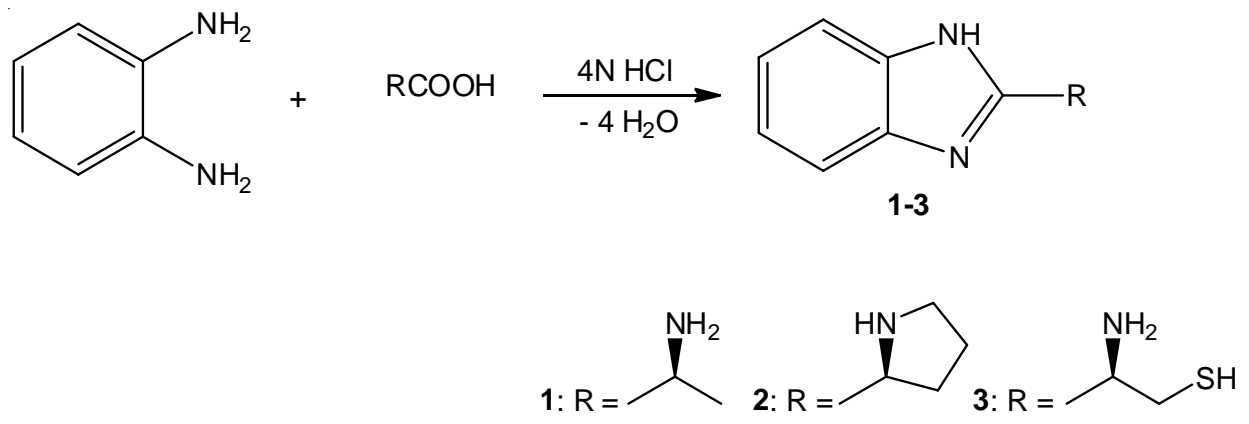

Scheme 1. The synthesis of ligands 1-3

Organotin complexes ( $\left.\mathrm{Me}_{2} \mathrm{SnABzCl}\right)$ 4-6 were prepared by reaction of 2-Alkylaminobenzimidazole derivatives $(\mathrm{ABzH})$ 1-3 with $\mathrm{Me}_{2} \mathrm{SnCl}_{2}$ in aqueous alkaline medium at room temperature (Scheme 2). The composition of isolated complexes was confirmed by the findings obtained from elemental analyses. It has been found that in all $\mathrm{AbzH} \mathrm{1-3,} \mathrm{one} \mathrm{chloride} \mathrm{was}$ substituted by monoanionic ligands and yielded their corresponding mononuclear complexes. Thus, ligands (1) and (2) behave in the Bidentate $N, N$ donor fashion, however, ligand 3 behave in the bidentate $\mathrm{N}, \mathrm{S}$ donor. This result may be explained by the considerable simultaneous acidic and nucleophile behave of sulfur in mercaptan group ${ }^{29}$ (Table 1). Characterization of synthesized complexes and their nature of bonding were examined by spectroscopic investigations.

$$
\mathrm{ABzH}+\left(\mathrm{CH}_{3}\right)_{2} \mathrm{SnCl}_{2} \underset{\mathrm{RT}}{\stackrel{\mathrm{NaOH} / \mathrm{H}_{2} \mathrm{O}}{\longrightarrow}}\left(\mathrm{CH}_{3}\right)_{2} \mathrm{Sn}(\mathrm{ABz}) \mathrm{Cl}+\mathrm{H}_{2} \mathrm{O}
$$

Scheme 2. Synthesis of complexes 4-6 with 2-alkylaminobenzimidazoles $(\mathrm{ABzH})$

\section{FT-IR}

All ligands $(\mathrm{ABzH})$ 1-3 display broad medium stretching vibrational band $(\mathrm{n}(\mathrm{N}-\mathrm{H}))$ at $3450 \mathrm{~cm}^{-1}$, which does not change on complexation ${ }^{28}$. However, as well used as hydrochloride benzimidazoles, the broad bands at $3150-2400 \mathrm{~cm}^{-1}$ corresponding to $\mathrm{n}(\mathrm{N}+-\mathrm{H})$ stretching vibration disappear after reaction to create new bands at $500-600 \mathrm{~cm}^{-1}$ related to $\mathrm{Sn}-$ $\mathrm{C}$ stretching vibration. Thus, a medium or relatively weak band at $1625 \mathrm{~cm}^{-1}$ with a small shoulder at $1522 \mathrm{~cm}^{-1}$ due to stretching vibration of $\mathrm{C}=\mathrm{N}$, were considerably become larger and sharper (1633 and $1507 \mathrm{~cm}^{-1}$ ) confirming the complexation with tin atom in all complexes 4-6 $6^{28}$. Moreover, the medium intensity band at $2525 \mathrm{~cm}^{-1}$, assigned to the $v(\mathrm{~S}+-\mathrm{H})$ vibration in the free ligand 3 , has not been observed in the spectra of the corresponding complex (6), while, a short band has been appeared in the $421 \mathrm{~cm}^{-1}$ range assigned to the $v(\mathrm{Sn}+-\mathrm{S})$ (Fig. 1). The above discussed data are in agreement with the deprotonation of the thiolic group after coordination on the tin center ${ }^{29}$. 
Table 1: Synthesized organotin complexes 4-6

Proposed
Complex structure Yield \%

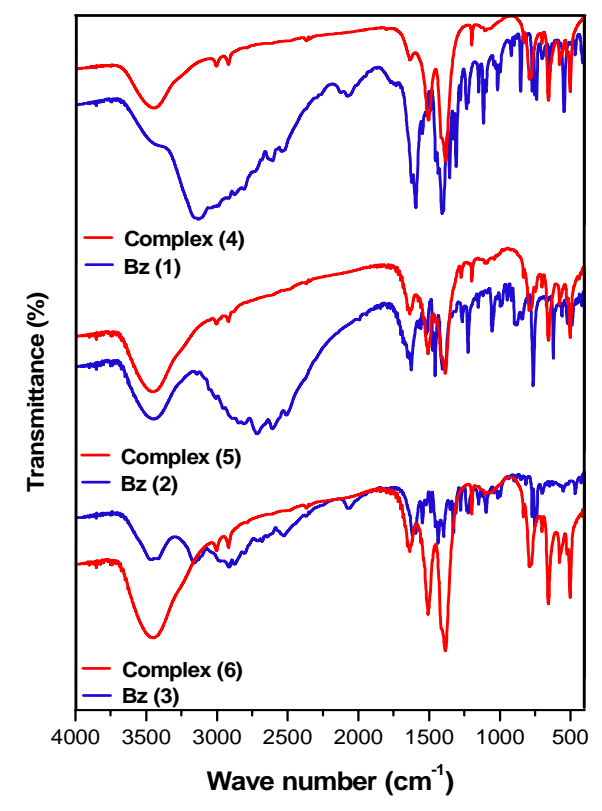

Fig. 1. Infra-red spectra of synthesized compounds

\section{UV-Vis studies}

The solutions of complexes 4-6 were prepared with DMSO at room temperature, and their concentration was $1 \times 10^{-5} \mathrm{~mol} / \mathrm{L}$. The spectrum showed the general appearance of absorption maxima for 2-alkylaminobenzimidazole moiety ${ }^{30}$ (Figure. 2).

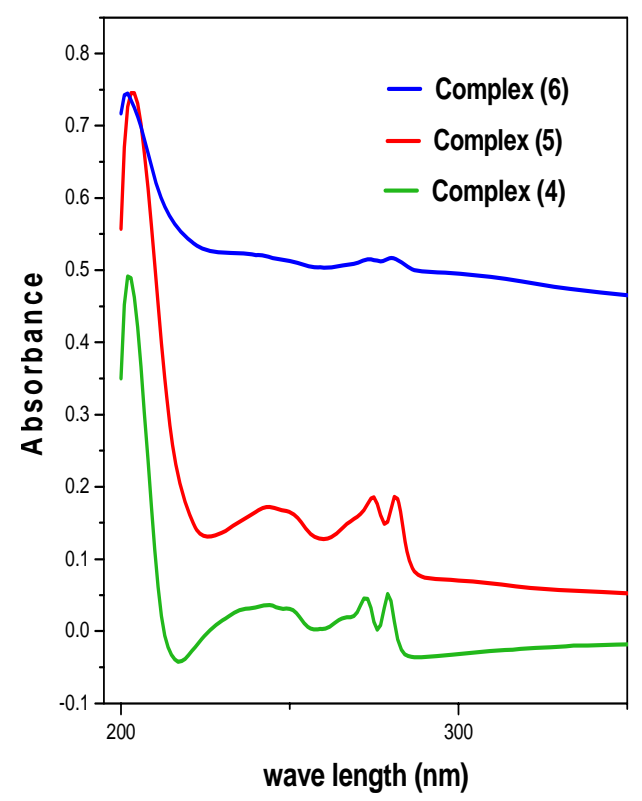

Fig. 2. Ultra-violet spectra of synthesized complexes

\section{NMR spectroscopy}

${ }^{1} \mathrm{H}$ NMR spectroscopy

The ${ }^{1} \mathrm{H}$ NMR spectra of tin complexes were measured in DMSO- $\mathrm{d}_{6}$ solution and exhibited signals with chemical shift values in accordance with their proposed structures. All complexes 4-6 
spectra showed signals at 10.8-10.5, 7.6-7.1, 4.314.62, and 1.50 which were assigned to the $\mathrm{NH}$ proton, chiral $\mathrm{CH}$, and the $\mathrm{CH}_{3}-\mathrm{Sn}^{31}$, correspondingly. The latter signals confirm simultaneously the presence of the tryptophan moiety in the complexes 4-632, and the noncoordination of $-\mathrm{NH}-$ group of tryptophan moiety on the tin atom ${ }^{28}$. In addition, the ligands (1) and (3) revealed $\mathrm{NH}_{2}$ proton signal at 1.61-1.76 $\mathrm{ppm}^{33}$ which has disappeared in the complexes (4) and (5) respectively, indicating coordination of the $-\mathrm{NH}_{2}$ group on the tin atom. Moreover, the ligand (2) showed $\mathrm{NH}$ (pyrrolidine group) proton signal at $2.16^{34}$ which has disappeared in the complex (5) suggesting probably coordination of $-\mathrm{NH}-$ moiety to the atom center. In complex (5), the ${ }^{1} \mathrm{H}$ NMR signals at $1.80-2.40,3.09-3.30$, and $4.64 \mathrm{ppm}$ indicates the presence of pyrrolidine group ${ }^{34}$. Furthermore in complex (6), cysteine moiety was confirmed by the presence of signals at 2.57 and $4.08 \mathrm{ppm}^{33}$. Thus, the appearance of signals at 1.63-1.78 indicates the presence of $-\mathrm{NH}_{2}$ group which confirms coordination of the deprotonated thiolate group on the tin center instead of the latter amino group ${ }^{29}$.

\section{${ }^{119}$ Sn NMR spectroscopy}

To investigate the ligand-binding modes to the tin atom in solution ${ }^{35},{ }^{119} \mathrm{Sn}$ NMR spectra was measured. It is generally recognized that ${ }^{119} \mathrm{~S} n$ chemical shifts are very sensitive either to the coordination modes and ligand types ${ }^{36}$. Thus, a range of $d$ values from +200 to -60 have been reported for four-coordinated, -90 to -190 for five-coordinated and -210 to -400 for six-coordinated diorganotin(IV) complexes in solution ${ }^{37}$. The chemical shift values for the synthesized compounds 4-6 are $-186,-204$, and -207 ppm, respectively confirming the penta-coordination mode.

\section{XRD analysis}

The XRD powder diffraction spectra of synthesized complexes were recorded with a scan rate about $0.02^{\circ} \mathrm{min}^{-1}$ and range $2 \theta=5-55$ degree (Fig. 3). The registered spectra revealed peak with maxima at $2 \theta=12.48-12.42, \mathrm{~d}=7.23-7.05^{\prime}$, and FWHM $=0.2503-0.2435$ (Fig. 4). All data are summarized in Table 2. The obtained results demonstrate closer parameters regarding to the first (maxima) peaks of XRD spectra for all complexes.

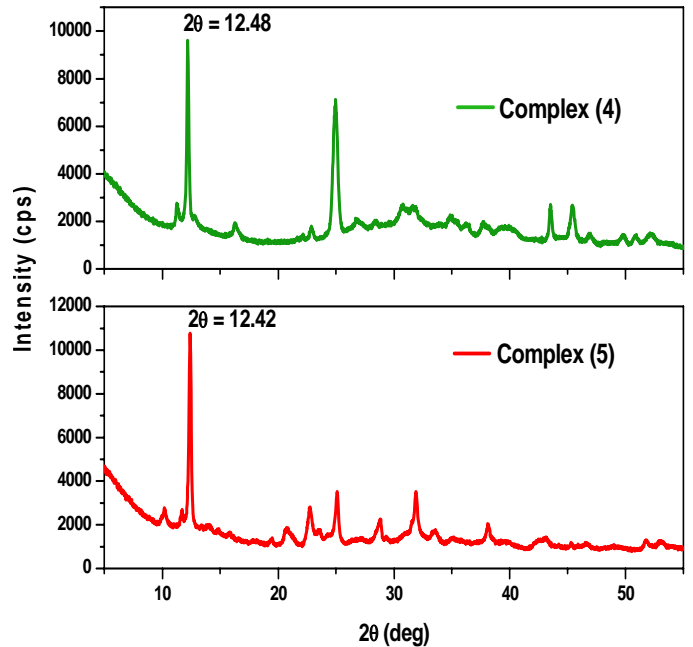

Fig. 3. XRD powder spectra of Sn Complex (4) and (5)

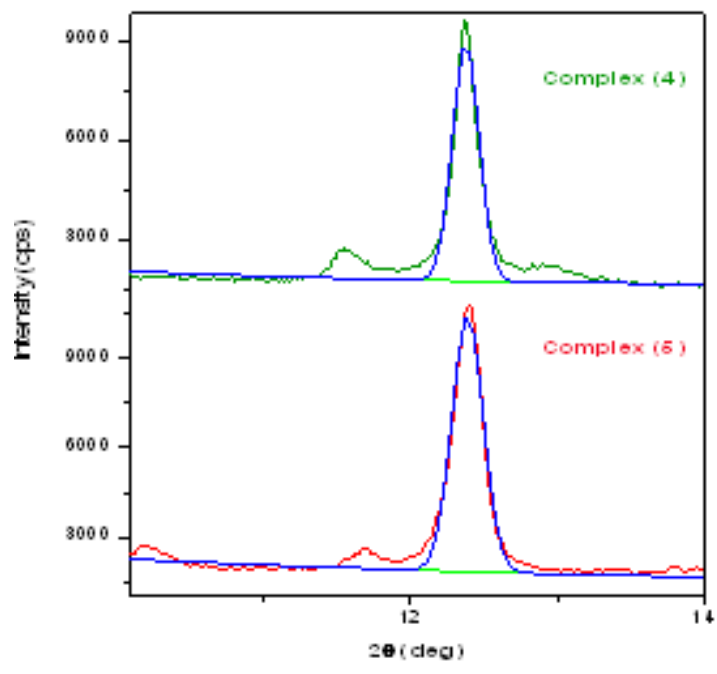

Fig. 4. Determining of FWHM and peak area parameter from the first peak (maxima) of Complex (4) and (5) by Origin software

Table 2: First peak (maxima) parameters of XRD spectra

First peak (maxima) parameters

\begin{tabular}{lcccc} 
& FWHM & $\begin{array}{c}\text { Peak } \\
\text { area }\end{array}$ & $2 \theta$ & $\begin{array}{c}\text { d-spacing } \\
{[\AA]^{*}}\end{array}$ \\
\hline Complex 4 & 0.2435 & 1883.7 & 12.48 & 7.23 \\
Complex 5 & 0.2503 & 2289.1 & 12.42 & 7.10 \\
Complex 6 & 0.2488 & 2161.4 & 12.45 & 7.05 \\
\hline
\end{tabular}

(*) d-spacing $[\AA]$ values were obtained by X'pert High Score software. 


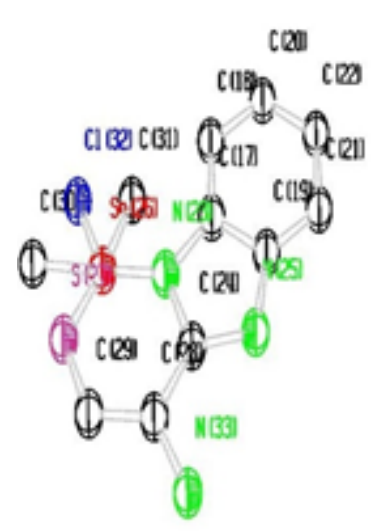

(a)

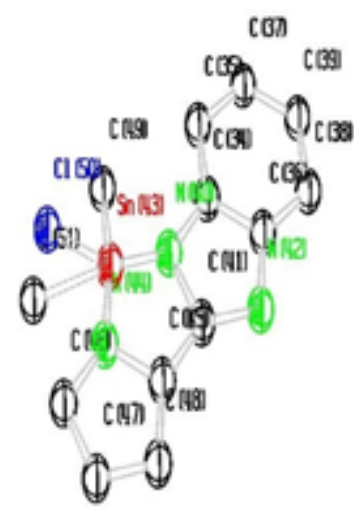

(b)

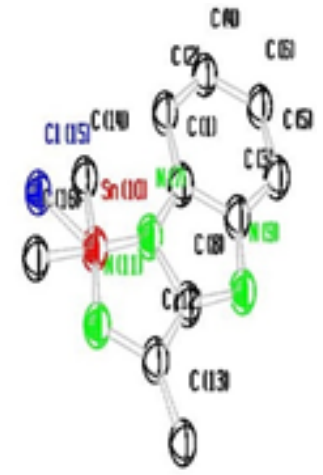

(c)

Fig. 5. Refined ORTEP drawing of the X-ray proposed structure of compounds: (a) complex (6), (b) complex (5), and (c) complex (4). Hydrogen atoms have been omitted

\section{Calorimetric measurements}

The differential scanning calorimetry measurements of synthesized complexes were recorded on heating between 200 and $800 \mathrm{~K}$ with a scanning rate $5 \mathrm{~K} \mathrm{min.-1}^{-1}$ (Fig. 6). The first thermogram showed the combustion of organic part of complex (4) which located at $592 \mathrm{~K}$. The values of enthalpy and entropy were resulted from the peak area are as follow: $\Delta \mathrm{H}=-774.8 \mathrm{~kJ} / \mathrm{mol}$ and $\Delta \mathrm{S}$ $=-1.5 \mathrm{~kJ} \mathrm{~mol}^{-1} \mathrm{~K}^{-1}$.

The second thermogram revealed the combustion of complex (5), which was achieved in three steps; at 473, 568, and $638 \mathrm{~K}$, correspondently. The values of enthalpy and entropy were determinate from the peak area are as follow: $\Delta \mathrm{H}=$ $668 \mathrm{~kJ} / \mathrm{mol}$ and $\Delta \mathrm{S}=-1.2 \mathrm{~kJ} \mathrm{~mol}^{-1} \mathrm{~K}^{-1}$.

The third thermogram displayed the combustion of complex (6), which was completed in three steps located at $555 \mathrm{~K}, 588 \mathrm{~K}$, and $652 \mathrm{~K}$, respectively. The values of enthalpy and entropy

\section{EXPERIMENTAL}

\section{Apparatus and materials}

The melting point of complexes was recorded by a differential scanning calorimetric instrument (DSC 131 evo-Setaram, France). The IR spectra were measured using a Nicolet iS5 Infrared Spectrometer in $\mathrm{KBr}$ (Thermo Scientific, USA).). ${ }^{1} \mathrm{H}-\mathrm{NMR},{ }^{13} \mathrm{C}-\mathrm{NMR}$ and ${ }^{119} \mathrm{Sn}$ spectra were were obtained from the peak area are as follow: $\Delta \mathrm{H}$ $=-664 \mathrm{~kJ} / \mathrm{mol}$ and $\Delta S=-1.3 \mathrm{~kJ} \mathrm{~mol}^{-1} \mathrm{~K}^{-1}$.

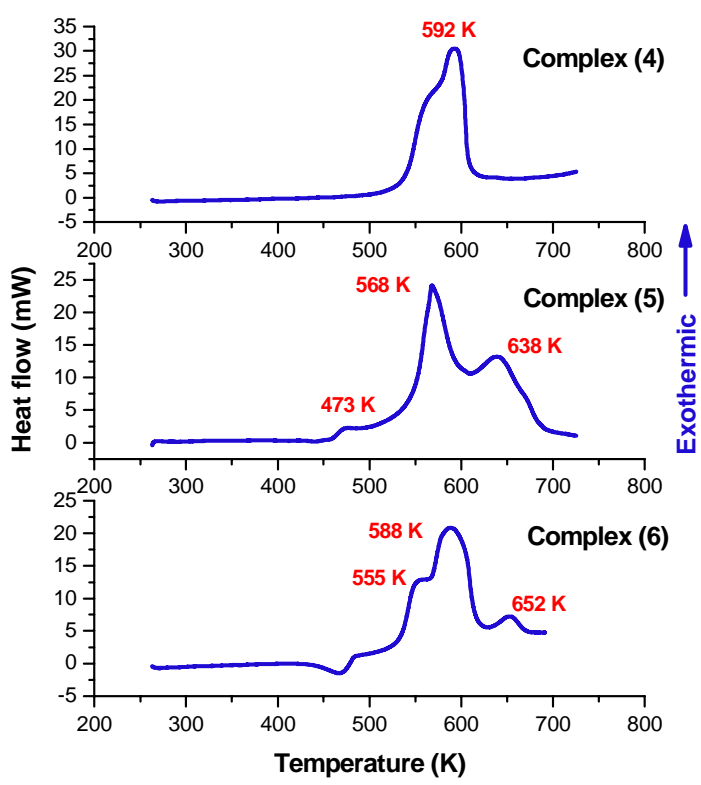

Fig. 6. DSC measurements of complexes 4-6

recorded by Bruker Avance 300 spectrometer (Bruker, France) at 300 and $75 \mathrm{MHZ}$, respectively. Chemical shifts were reported in ppm from internal TMS for ${ }^{1} \mathrm{H},{ }^{13} \mathrm{C}$ and ${ }^{119} \mathrm{Sn}$. Elemental analysis was obtained by means an Exeter Analytical CE-440 Elemental instrument (Exeter Analytical, UK). X-ray spectra were recorded by an Oxford X-calibur Gemini diffractometer (Santa Clara, California, USA) equipped with EOS CCD detector using 
monochromated Mo Ka radiation $\left(\mathrm{k}=0.71073 \mathrm{~A}^{\circ}\right)$ at room temperature. Dimethyltin dichloride, o-phenylenediamine, $\mathrm{L}(+)$-alanine, $\mathrm{L}(+)$-proline, and $L(+)$-cysteine were purchased from Sigma-Aldrich and used as received.

\section{Typical Procedure for the synthesis of complexes 4-6}

$\mathrm{ABzH} 1-3(5 \mathrm{mmol})$ were taken in $10 \mathrm{~mL}$ aqueous solution of $\mathrm{NaOH}(5 \mathrm{mmol})$ and stirred at room temperature for 20 minutes. After that, an aqueous solution of dimethyltin dichloride (5.5 mmol) was added dropwise with continuous stirring. After couple of minutes stirring, a pale yellow powder was precipitated, which was filtered out, washed simultaneously with water and ethanol and recrystallized from a mixture ethanol/DMSO (95/5).

\section{$\left[\left(\mathrm{CH}_{3}\right)_{2} \mathrm{Sn}\left(\mathrm{C}_{9} \mathrm{H}_{10} \mathrm{~N}_{3}\right) \mathrm{Cl}\right]$ (4)}

M.p. 480-482 K; Calc. for $\mathrm{C}_{11} \mathrm{H}_{16} \mathrm{CIN}_{3} \mathrm{Sn}(\%)$ : C, 38.36; H, 4.68; N, 12.20. Found: C, 38.34; H, 4.66; N, 12.18; Selected IR data (KBr) [v/cm-1]: 3449 $v(\mathrm{NH}) ; 1633$ and $1507 v(\mathrm{C}=\mathrm{N}) ; 780 v(\mathrm{Ar}) ; 576$ v(Sn-C); 500 v(Sn-N);. UV-Vis (EtOH) $[\lambda \max / \mathrm{nm}]$ 202, 272, 279. ${ }^{1} \mathrm{H}$ NMR (DMSO-d $\left.\mathrm{d}_{6}, \mathrm{ppm}\right): 1.5$ $\left(\mathrm{CH}_{3}-\mathrm{Sn}\right) 4.3(-\mathrm{CH})$; 7.6-7.2 (Harom); $10.8(\mathrm{BzNH})$. ${ }^{13} \mathrm{C}$ NMR (DMSO-d,$\left.p p m\right): 151(\mathrm{C}=\mathrm{N}) ; 114-128$ (Carom); $46(\mathrm{CH}) ; 22\left(-\mathrm{CH}_{3}\right), 8.1\left(\mathrm{CH}_{3}-\mathrm{Sn}\right) .{ }^{119} \mathrm{Sn}$ NMR (DMSO-d, ppm): -186 .

\section{$\left[\left(\mathrm{CH}_{3}\right)_{2} \mathrm{Sn}\left(\mathrm{C}_{9} \mathrm{H}_{12} \mathrm{~N}_{3}\right) \mathrm{Cl}\right](5)$}

M.p. 453-455 K; Calc. for $\mathrm{C}_{13} \mathrm{H}_{18} \mathrm{CIN}_{3} \mathrm{Sn}(\%)$ :

C, 42.15; H, 4.90; N, 11.34. Found: C, 42.14; H, 4.88;

$\mathrm{N}, 12.32$; Selected IR data $(\mathrm{KBr})[\mathrm{v} / \mathrm{cm}-1]: 3451$ $v(\mathrm{NH}) ; 1637$ and $1507 v(\mathrm{C}=\mathrm{N}) ; 792 v(\mathrm{Ar}) ; 579$ v(Sn-C); 500 v(Sn-N). UV-Vis (EtOH) $[\lambda \max / \mathrm{nm}]$ : 203, 274, 281. ${ }^{1} \mathrm{H}$ NMR (DMSO-d ${ }_{6}$, ppm): $1.5\left(\mathrm{CH}_{3}-\mathrm{Sn}\right)$; 1.4-2.4 (m, - $\left.\mathrm{CH}_{2}-\mathrm{CH}_{2}-\right)$; 3.1-3.3 ( $\left.\mathrm{CH}-\mathrm{NH}-\mathrm{CH}_{2}-\right)$; 4.6 (-CH); 7.1-7.6 (Harom), 10.5 (BzNH). ${ }^{13} \mathrm{C}$ NMR
(DMSO-d, ppm): $154(\mathrm{C}=\mathrm{N}) ; 115-129$ (Carom); $46(\mathrm{CH}) ; 21\left(-\mathrm{CH}_{3}\right) ; 8.4\left(\mathrm{CH}_{3}-\mathrm{Sn}\right) .{ }^{119} \mathrm{Sn}$ NMR (DMSO$\left.\mathrm{d}_{6}, \mathrm{ppm}\right):-204$

\section{$\left[\left(\mathrm{CH}_{3}\right)_{2} \mathrm{Sn}\left(\mathrm{C}_{9} \mathrm{H}_{10} \mathrm{~N}_{3} \mathrm{~S}\right) \mathrm{Cl}\right](6)$}

M.p. $485-487 \mathrm{~K} ; \mathrm{C}_{11} \mathrm{H}_{16} \mathrm{CIN}_{3} \mathrm{SSn}(\%)$ : $\mathrm{C}$ 35.09; H, 4.28; N, 11.16. Found: C, 35.08; H, 4.26; N, 11.15; Selected IR data (KBr) [v/cm-1]: $3450 v(\mathrm{NH})$; 1636 and $1507 v(\mathrm{C}=\mathrm{N}) ; 788$ v(Ar); 576 $v(\mathrm{Sn}-\mathrm{C}) ; 501 v(\mathrm{Sn}-\mathrm{N})$. UV-Vis $(\mathrm{EtOH})[\lambda \max / \mathrm{nm}]$ : 201, 273, 280. ${ }^{1} \mathrm{H}$ NMR (DMSO-d, $\left.\mathrm{ppm}\right): 1.4\left(\mathrm{CH}_{3}-\mathrm{Sn}\right)$ $2.6\left(\mathrm{CH}_{2}-\mathrm{SH}\right) 4.0(-\mathrm{CH}) ; 7.1-7.6$ (Harom), 10.6 $(\mathrm{BzNH}) .{ }^{13} \mathrm{C}$ NMR (DMSO-d, ppm): $154(\mathrm{C}=\mathrm{N})$; 117-130 (Carom); $44(\mathrm{CH}) ; 23\left(-\mathrm{CH}_{3}\right) ; 8.2\left(\mathrm{CH}_{3}-\mathrm{Sn}\right) .{ }^{119} \mathrm{Sn}$ NMR (DMSO-d $\left.{ }_{6}, \mathrm{ppm}\right):-207$.

\section{CONCLUSION}

Chiral penta-coordinate organotin(IV) complexes were successfully prepared and characterized using different analytical techniques. The obtained spectroscopic data were accordant with the proposed structures of products. The complexes (4) and (5) were resulted via N,N coordination to tin atom by their analogous ligands (1) and (2), respectively, whereas, the complex (6) was achieved by $N, S$ chelation of tin center. The XRD spectra of compounds revealed closer parameters about the first (maxima) peak. DSC studies showed that the decomposition of the complexes proceeded via exothermic combustion.

\section{ACKNOWLEDGMENT}

The authors wish to acknowledge the approval and the support of this research study by the grant $\mathrm{N}^{\circ}$. SCl-2016-1-6-F-4679 from the Deanship of Scientific Research in Northern Border University, Arar, KSA.

\section{REFERENCES}

1. Xiao, X.; Liang, J.; Xie, J.; Liu, X.;Zhu, D.; Dong, Y. J. Mol. Struct., 2017, 1146(15), 233-241.

2. Basu Baul, T. S.; Kehie, P.; Duthie, A.; Guchhait, N.; Raviprakash, N.; Mokhamatam, R. B.; Manna, S. K; Armata, N.; Scopelliti, M.; Wang, R.; Englert, U. J. Inorg. Biochem., 2017, 168, 76-89.

3. Javed, F.; Sirajuddin, M.; Ali, S.; Khalid, N.;
Tahir, M. N.; Shah, N. A.; Rasheed. Z.; Khan, M. R. Polyhedron., 2016, 104, 80-90.

4. Saeed, A.; Channar, P. A.; Larik, F. A.; Jabeen, F.; Muqadar, U.; Saeed, S.; Flörke, U.; Ismail, H.; Dilshad, E.; Mirza, B. Inorg. Chim. Acta., 2017, 464, 204-213.

5. Niu, L.; Li, Y.; Li, Q. Inorg. Chim. Acta Part B., 2014, 423, 2-13. 
6. Tariq, M.; Muhammad, N.; Sirajuddin, M.; Ali, S.; Shah, N. A.; Khalid, N.; Tahir, M. N.; Khan, M.R. J. Organomet. Chem., 2013, 723, 79-89.

7. El-Khalafy, S. H.; Hassanein, M. T.; Etaiw, S. E. H.; Badr El-Din, A. S. Arab. J. Chem., 2017, 10, 2, S2829-S2835.

8. Etaiw, S. E. H.; El-bendary, M. M.; Appl. Catal., B: Environmental., 2012, 126, 326-333.

9. Henno P. van Dokkum, Sherri L. Huwer, Regul. Toxicol. Pharm., 2005, 41(1), 73-81.

10. Flick, E. W. Plastics Additives (Third Edition)., 2002, 10-23.

11. Davies, A. G. Organotin Chemistry (second edition)., (2004).

12. Teo, S.-B.; Teoh, S.-G.; Okechukwu, R. C.; Fun, H.-K. Polyhedron., 1994, 13, 2223-2228.

13. Vasnin, S.V.; Cetrullo, J.; Geanangel, R. A.; Beranl, J. Inorg. Chem., 1990, 29, 885-888.

14. Pettinari C.; Marchetti, F.; Pellei, M.; Cingolani, A.; Barba, L.; Casetta, A. J. Organomet. Chem., 1996, 515, 119-130.

15. Pettinari, C.; Pellei, M.; Marchetti, F.; Santini, C.; Miliani, M. Polyhedron., 1998, 17, 561-576.

16. Pettinari, C.; Marchetti, F.; Cingolani, A. Polyhedron,, 1996, 15, 1263-1276.

17. Lobbia, G. G.; Bonati, F.; Ceechi, P.; Leonesi, D. J. Organomet. Chem., 1990, 391, 155-163.

18. Das, V. G. K.; Keong, Y. C.; Wei, C.; Smith, P. J.; Mak, T. C. W. J. Chem. Soc., Dalton Trans., 1987, 129-137.

19. Davies, A. G. and Smith, P. J. Chap. 11 in G. Wilkinson, Stone, F. G. A. and Abel, E.W. (eds) Comprehensive Organometallic Chemistry, Pergamon Press, Oxford., 1982, 2, 519-627.

20. Dittmer, A.;Woskobojnik, I.; Adfeldt, R.; Drach, J. C.; Townsend, L. B.; Voigt, S.; Bogner, E. Antiviral Research., 2017, 137, 102-107

21. Tonelli, M.; Novelli, F.; Tasso, B.; Vazzana, I.; Sparatore, A.; Boido, V.; Sparatore, F.; La Colla, P.; Sanna, G.; Giliberti, G.; Busonera, B.; Farci, P.; Ibba, C.; Loddo, R. Bioorg. Med. Chem., 2014, 22, 4893-4909.

22. Shahini, C. R.; Achar, G.; Budagumpi, S.; Tacke, M.; Patil, S. A. Inorg. Chim. Acta., 2017, 466, 432-441.

23. Moreira, J. B.; Mann, J.; Neidle, S.; McHugh,
T. D.; Taylor, P. W. Int. J. Antimicrob. Agents., 2013, 42, 4, 361-366.

24. (a) Stinson, S.C.; Chem. Eng. News 2001, 79, 45-56; (b) Xiaogang, Q.; Trent, J. O.; Fokt, I.; Priebe, W.; Chaires, J. B. Proc. Natl. Acad. Sci. U.S.A., 2000, 97, 12032-12037.

25. Miao, T.-F.; Xu, L.-C.; Miao, Q.-Q.; Wang, Q.Q., Wang, N.-L. Inorg. Chim. Acta., 2015, 43474-43478.

26. Zhou, X.-Q.; Li, Y.; Zhang, D.-Y.; Nie, Y.; Li, Z.J.; Gu, W.; Liu, X.; Tian, J.-L.; Yan, S.-P. Eur. J. Med. Chem., 2016, 114, 244-256

27. Phillips, M. J. Chem. Soc. C., 1928, 2393.

28. Tavman, A.; Ülküseven, B. Trans. Met. Chem., 2000, 25, 324-328.

29. (a) Pellerito, L.; Prinzivalli, C.; Casella, G.;Fiore, T.; Pellerito, O.; Giuliano, M.; Scopelliti, M.; Pellerito C. J. Inorg. Biochem., 2010, 104, 750-758. (b) Domazetis, G.; Magee, R. J.; James, B. D. J. organometal. Chem., 1978, 162, 239.

30. Steck, E. A.; Nachod, F. C.; Ewing, G. W.; Gorman, N. H. J. Am. Chem. Soc., 1948, 70, (10), 3406-3410.

31. Sedaghat, T.; Goodarzi, K. Phosphorus. Sulfur. Silicon Relat. Elem., 2007, 182, 2227-2233.

32. (a) Alatorre Santamaria, S.; GotorFernández, V. Eur. J. Org. Chem., 2009, 15, 2533-2538; (b) Li, Y.; Ding, K.; Sandoval, C.A. Org. Lett., 2009, 11, 907-910.

33. (a) Chen, R.-H.; Xiong, J.-F.; Peng, P.; Mo, G.Z.; Tang, X.-S.; Wang, Z.-Y.; Wang, X.-F. Asian J. Chem. 2014, 26, 3, 926-932; (b) Peng, P.; Xiong, J.F.; Mo, G.Z.; Zheng, J.L.; Chen, R.H.; Chen, X.Y.; Wang, Z.Y. Amino Acids., 2014, 46, 2427-2433.

34. Reddy, K. R.; Krishna, G. G.; Rajasekhar, C. V. Synth. Commun., 2007, 37, 4289-4299.

35. Pettinari, C. in: J.C. Lindon (Ed.), Heteronuclear NMR Applications (Ge, Sn, Pb), Encyclopedia of Spectroscopy and Spectrometry, Academic Press, London., 1999.

36. Damude, L. C.; Dean, P. A. W.; Masivannman, V.; Srivastava, R. S.; Vitali, J. J. Can. J. Chem., 1990, 68, 1323-1331.

37. Holeèek, J., Nádvorník, M.; Handlíø, K.; Lyèka, A. J. Organomet. Chem., 1986, 315, 299-309. 